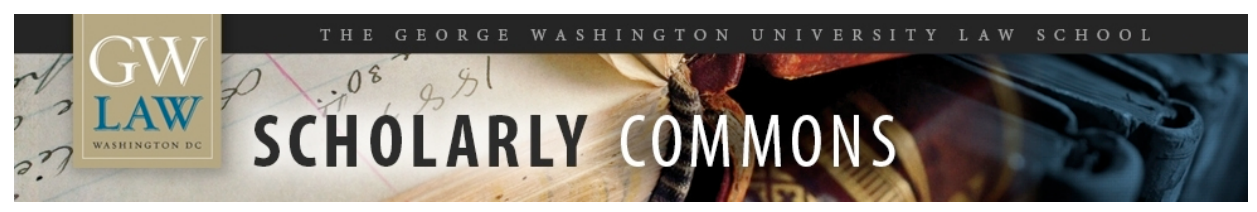

\title{
The Role of Non-Legal Institutions in Chinese Corporate Governance
}

Donald C. Clarke

George Washington University Law School, dclarke@law.gwu.edu

Follow this and additional works at: https://scholarship.law.gwu.edu/faculty_publications

Part of the Law Commons

\section{Recommended Citation}

Transforming Corporate Governance in East Asia 168 (Hedeki Kanda et al. eds., 2008)

This Article is brought to you for free and open access by the Faculty Scholarship at Scholarly Commons. It has been accepted for inclusion in GW Law Faculty Publications \& Other Works by an authorized administrator of Scholarly Commons. For more information, please contact spagel@law.gwu.edu. 


\section{Transforming Corporate Governance in East Asia}

Edited by

Hideki Kanda, Kon-Sik Kim and Curtis J. Milhaupt

Routledge 


\section{The role of non-legal institutions in Chinese corporate governance}

\author{
Donald C. Clarke
}

\section{Introduction}

Chinese corporate governance has recently become a popular subject of academic research. Scholars of economics and business have tried to test the relationships between performance and corporate governance, each measured in various ways. Legal scholars have looked both at the substantive norms and, to a lesser extent, at the institutions-for example, the court system and the China Securities Regulatory Commission-for enforcing those norms.

Little attention has yet been paid, however, to the institutions outside the state regulatory structure that make up the environment in which corporate governance norms, both formal and informal, are expected to function. ${ }^{1}$ This chapter focuses on these non-state institutions and the degree to which they can support the realization of corporate governance norms.

Although this chapter purports to be about non-state institutions, to speak of non-state institutions in China courts inaccuracy. The Chinese political system does not fundamentally accept the existence of an independent civil society; in principle, the state permits the existence of no organization not subject to government direction. Any institution of any influence is going to be subject to at least some degree of state direction. Moreover, I include within the category of "non-state institutions" certain mechanisms and structures (for example, independent directors) that ultimately depend in some sense on the state legal system for their effectiveness. Even though a clear line cannot, therefore, be drawn between state and nonstate institutions of corporate governance, I believe that it is still useful to attempt to single out the latter for special examination, if for no other reason than that so far so much attention has been concentrated on the former.

There is also a more important reason: non-state institutions can 'contribute to more effective corporate governance if allowed to do so. China's corporate governance regime relies heavily on the announcement of rules by government authorities and relatively little on institutions for making those rules meaningful. Lawmakers seem to expect that regulated parties will read the legal texts and voluntarily obey; if they do not, their lack of "legal consciousness" (falü yishi) is generally blamed, not the lack of institutions (state or non-state) that would require them to obey, whether they had the requisite legal consciousness or not.

At the same time, the corporate governance regime does not look to nonstate institutions for the making and enforcement of rules and standards. One reason for this is simply political: as noted above, China's current political system does not accept the existence of institutions that are both powerful and independent of the state. Furthermore, both Imperial China and China under the planned economy have left their legacy in official culture: state officials find it hard to believe that the unplanned workings of the market might produce a better set of rules or procedures than they could come up with themselves.

Yet in relying on the state legal and administrative system to make and enforce norms, the state has in a sense chosen to play its weakest card. For all its progress over the quarter century, the post-Mao Chinese legal system remains an institution of only modest importance in the polity. It may be that institutions outside the state legal system could do much more than they now do.

\section{Non-state institutions of corporate governance in China}

This chapter will generally (but not exclusively) focus on a narrow conception of corporate governance. It centers on issues of agency cost and has a normative goal: preventing those who control corporate assets from exploiting those (in particular, equity holders) who supply them (Jensen and Meckling 1976).

This limited conception of corporate governance contains two types of agency problem: vertical (the exploitation of shareholders as a whole by management) and horizontal (the exploitation of minority shareholders by controlling shareholders). In each case, the exploiter extracts rents or private benefits, but can do so in different ways, and the means of mitigating such exploitation are different (Roe 2004). In addition, mitigating one kind of agency cost may mean exacerbating another. Dispersed shareholding, for example, can lead to high vertical agency costs, because collective action problems make it difficult for shareholders to monitor management. But one solution-concentrated shareholdings-may result in higher horizontal agency costs (Roe 2004).

In the United States, the main agency cost problem is vertical; in the rest of the world, however, and especially in transition economies, it is horizontal (La Porta et al. 1998; Denis and McConnell 2003). This chapter will show that China seems to be no exception to this pattern. What makes China exceptional is the identity of the controlling shareholder that is doing the exploiting: in most cases, it either is or is closely connected with a governmental entity. For this reason, some mechanisms for dealing with 
controlling-shareholder problems that work outside of China may not work within it because the controlling shareholder is too powerful.

This is just a specific example of a more general proposition: that rules and norms of corporate governance cannot be understood in the abstract. They function-or fail to function - within a particular institutional environment, and understanding and critiquing the rules requires understanding that environment.

Chinese commentators often complain, for example, that the rules of the Company Law are too broadly worded and not readily put into practice. Certainly this is sometimes true: how, for example, should one understand "relatively small in scale" in Article 52 of the new Company Law? But sometimes the expectations of the critics seem unrealistic. No rule formulated ex ante can spell everything out; the key is to have an alternative system available to supplement legislative gaps. Often the detailed standards that commentators cite with approval come not from the ex ante legislation of other jurisdictions but from case law. ${ }^{2}$

Commentators also complain that even when the Company Law's rules are clear, regulated parties do not obey them, and that the structures provided by the law, such as the board of supervisors, remain decoratively on the shelf but do not function as intended. Although they tend to blame the actors for failing to live up to the law's expectations, the real fault arguably lies in the law's inattention to enforcement mechanisms, in particular those that can be activated by parties hurt by non-compliance.

This chapter does not examine enforcement mechanisms (such as they are) that exist as formal state institutions. Instead, it looks at some particular examples of non-state (or semi-state) institutions in order to show both their abstract potential for playing a role in corporate governance and the specific possibility of their doing so in China.

\section{Markets in general}

There are several institutions that align the interests of managers and shareholders (Roe 2004). Among these are markets of various kinds-product markets, capital markets, and labor markets--because to the extent that a corporate governance scheme does not rely on public or private enforcement of legal obligations or simply the good conscience of parties to the corporate enterprise, it relies on markets to pressure parties to do the right thing. Those markets impose a certain discipline on management, but the constraints are not tight. It may take some time for selection pressures to affect firms operating sub-optimally. ${ }^{3}$

At the beginning of economic reform in China, markets did discipline managers, because very little economic activity of importance took place on a market basis. Over time, the importance of product and other markets has increased. Nevertheless, a number of companies remain in protected markets; this gives their management considerable slack.

The role of non-legal institutions in Chinese corporate governance

The role of stock markets and external debt in corporate finance and corporate governance

Two markets of potential importance for Chinese corporate governance are those for external debt and for equity financing.

\section{Historical background}

Before the reform era, there was no financial market in the sense of firms seeking financing by offering competitive terms, or suppliers of funds offering financing in the same way. The traditional state-owned enterprise (TSOE) received all its funding from government bureaux of various kinds. There were banks that performed an intermediation function by collecting the funds of individual depositors, to be sure, but they passed these funds on to firms according to government direction, acting essentially as cashiers (Lardy 1998).

If the firm received money directly from a state body, the funds would be characterized as a grant; if the money came from a bank, it would be called a loan. But even if the funds came with the label of "loan," firms operated under a soft budget constraint and were under no particular pressure to repay. While firms still competed for money, they did so on a bureaucratic, not a market basis.

This system began to undergo reform in the 1980s. The People's Bank of China (PBOC) was carved out from the Ministry of Finance and set up as a central bank in 1984, with conventional banking to be handled by four specialized state-owned banks (the "Big Four") (Lardy 1998; U.S. Commercial Service 2007).

The 1990s saw the emergence of rivals to the Big Four state-owned banks and an effort to move toward more market-based lending. The so-called "policy banks" were created to handle non-market-based lending, and the government authorized the creation of domestic joint-stock banks owned by local governments together with other institutional and occasionally private investors. While these banks may be more profit oriented than the Big Four, they are still subject to significant political influence in their functioning and have not been able to escape the obligation to make "policy loans" (Green 2003a: 22). If local political leaders think a favored enterprise should get a loan, it generally gets it.

In part as a result of these political considerations, bank lending grew faster than the economy during much of the 1990s, and the non-performing loan (NPL) holdings of the banks grew concomitantly. By the late 1990s, the system was insolvent (Green 2003a: 22).

Although the stock markets had been in existence since 1990, it was in 1996 that national leaders, looking for an alternative to bank lending, turned to them as a way of providing a new source of financing for the troubled state sector. This marked the beginning of unequivocal state 
support for stock markets. It also solidified some key features of the Chinese stock markets: first, that their primary role has been not to allocate capital to the most efficient enterprises, but to raise money for restructuring SOEs (Zhang 2004: 2044), and second, that the state has been both regulator and cheerleader, with the specific mission of keeping stock prices up in order to support the financing of SOEs.

\section{The stock market since the mid-2000s}

Given the support China's stock markets have received from the state, it is not surprising that much writing on them assumes that they are critical to the Chinese economy. At least until very recently, this assumption has been questionable.

As of the end of 2005, China's two stock markets listed 1,381 companies, with a circulating share ${ }^{4}$ capitalization of 1.06 trillion yuan (approximately $\$ 132$ billion) (CSRC website, 1 September 2007), or 6 percent of gross domestic product in that year. At that amount, China ranked around twentieth in the world in terms of absolute market capitalization. Looking at market capitalization as a percentage of GDP, the United States showed 150 percent in 2002, while Hong Kong showed 300 percent in 2005. Other transition economies such as the Czech Republic and Russia each show about 25 percent. In short, the stock market is not large by any measure.

Why, then, were there at the same time widespread claims that China's market capitalization was about US $\$ 500$ billion (e.g., Bai et al. 2003; AFP 2006; Securities Industry Association 2003), ranking China ahead of Hong Kong and behind only Japan in Asia? The answer is that such claims unrealistically valued non-circulating shares as if they were circulating shares. All the available empirical evidence shows that non-circulating shares-historically as much as two-thirds of capital stock-sell at a large discount to circulating shares, sometimes by as much as 90 percent (Chen and Xiong 2002; Chen et al. 2000). ${ }^{5}$ An economically realistic valuation would therefore be much lower.

Beginning in the spring of 2006, the market capitalization of Chinese listed companies, however measured, rose dramatically. In the 14 months from the end of March 2006 to the end of May 2007, the market capitalization with all shares valued (unrealistically) equally rose from 3.54 trillion yuan (US\$468 billion) to 17.8 trillion yuan (US\$2.36 trillion). The market capitalization of circulating shares rose from 1.23 trillion yuan (US\$164 billion) to 5.94 trillion yuan (US\$786 billion) in the same period (CSRC website, 1 September 2007). This certainly makes Chinese stock markets more important than previously. At the same time, however, the current market surge may be a bubble. ${ }^{6}$ By some measures, Chinese market capitalization exceeded Japan's as of late August 2007 (Dyer 2007a), a result that seems hard to justify. ${ }^{7}$

In terms of funds raised for investment, the stock markets do not loom large. In 2002, for example, the stock market provided only about 5 percent of external corporate financing: US\$8.9 billion compared with US\$217.7 billion from bank loans (Green 2003b; Green 2003a: 29; Allen, Qian, and Qian 2002: 17-19). More recently, statistics for the first quarter of 2006 show that bank loans constituted an overwhelming 91.3 percent of external financing for non-financial institutions ${ }^{8}$ in China, compared with a paltry 0.5 percent share for equities (PBOC 2006: 13). On the whole, then, "[b]oth the scale and relative importance (compared with other channels of financing) of China's external markets are not significant." (Allen, Qian, and Qian 2005: 73.)

There are many reasons for the tiny amount of investment funded through equity issues. One is, of course, simply the youth of China's stock markets-they have been around only since the early 1990s. But there is more to it than that. More important is that equity financing has been repressed through state regulation.

First, initial public offerings were subject to a state-administered quota until 2000, and even now must be approved by the China Securities Regulatory Commission (CSRC), which continues to exercise control over the number and type of listings (Pistor and Xu 2004; Green 2003a: 160-4). Because the key role of the stock market is to raise funds for restructured SOEs (Green 2003a: 22), it is necessary to restrict the supply of equity securities in order to keep prices high. And prices have been high: in September 2002, for example, the average price/earnings (PE) ratio of Chinese listed companies was 40 to 50 , and one in seven companies had a PE ratio of over 100 (Walter and Howie 2003; 136). ${ }^{9}$

Second, a significant portion of the stock of listed companies-approximately two-thirds-has been kept off the markets in non-circulating form. Even when SOEs listed, therefore, their state shareholders were forbidden by state policy from listing more than about one-third of their shares. This policy stemmed from a fear of privatization.

Third, regulations on share issues have a strong paternalistic flavor and attempt to make investment in securities as safe as possible. Prior to the 2005 revisions to the Company Law and the Securities Law, companies wishing to make a public issue of stock had to show profits for the preceding three years. ${ }^{10}$ Such a rule favors established, stable companies such as large SOEs-precisely the companies that probably already have reasonably good access to bank loans. It automatically rules out young companies or companies whose business plan calls for initial losses funded by equity, to be set off by later profits. In other words, equity financing in the stock market has in principle been conceived as a supplement to debt financing, not as an alternative source of financing for companies that are, for one reason or another, unsuited to debt financing.

This bias has consequences not only for the economy-new firms whose main asset is the opportunity for growth will find it especially hard to get off the ground (La Porta et al. 2000: 19)-but for corporate governance as well. To the extent that the equity markets remain dominated by firms with 
a large state ownership stake, the rules and practices governing the relationships among minority shareholders, controlling shareholders, directors, supervisors, and management will have to take account of the special character of the controlling shareholder-a state institution. Moreover, what happens on the circulating share market will have a smaller disciplining effect upon management when the proportion of shares on that market is so small.

What about investors? China is often said to have 60 to 70 million stock market investors (see, e.g., Beijing Modern Business News 2005). This is, however, a wholly fanciful number based, among other things, on the premise that each stock account equals a separate investor, a transparently false assumption-investors typically hold an account at each of China's two stock exchanges-that was debunked years ago in both Chinese (e.g., Tianjin Daily 2001) and English sources. In 2003, Walter and Howie (2003: 48 ), on the basis of a variety of data, put the number of actual holders of shares at five to ten million, and estimated the number of active traders to be from 500,000 to two million.

The 2007 stock market boom did bring many new investors into the market, " but still far fewer than is commonly assumed. As noted above, many investors hold duplicate accounts-one in Shanghai and one in Shenzhen-and some control many more than two. And remarkably, fully two-thirds of existing stock accounts hold no stock at all-possibly being held in reserve for market manipulation (Kroeber 2007).

Moreover, the picture of the average investor as a naive retiree staking his retirement savings is false. Only 17 percent are over 55, and they tend to play the market as a pastime, like bingo. ${ }^{12}$ Institutional investors, not fickle individuals, play the dominant role in market movements (Hong Kong Stock Exchange 2004).

Understanding who the investors are and how they behave has critical implications for corporate governance. First, it helps us understand whether equity markets can in fact serve a disciplining function. Do they respond to failures of corporate governance? Second, it helps us to assess the necessity and urgency of measures to help the small investor who, in the popular image of the stock market, is getting roughed up by the big boys. If small investors gave up hope and left, would it matter?

Current research presents a mixed picture. Knowledgeable commentators agree that institutional investors, not fickle individuals, play a large role in market movements. And the trading strategy they adopt is largely speculative: the average holding period in China is about one to two months, compared with 18 months in the United States (Xu and Wang 1999). ${ }^{13}$ In addition, China's stock markets have a high degree of synchronicity: one study found that 80 percent of the stocks listed on the two exchanges moved in the same direction in a given week (Morck et al. 2000; see also Durnev et al. 2004 and Fox et al. 2003). This degree of synchronicity is the second highest among stock markets in 40 countries; it suggests that stock prices move in response to information about the market in general, not about specific firms (Chang and Wong 2003: 25). In other words, Chinese investors rationally worry more about the latest twists and turns in government policy or other market-level rumors than about corporate results.

Although the above picture is the dominant one, it may not be entirely accurate. Studies have found, among other things, that investors pay a premium for better-governed companies (Bai et al. 2003: 22) and that they react to accounting numbers (Chen et al. 1999) - a seemingly banal result, but one that is inconsistent with the thesis that investors don't care about fundamentals.

Inconsistent as some of these findings are, it is nevertheless possible to draw a few tentative conclusions from existing research. First, the picture of the Chinese stock market as solely speculative is probably overstated. Investors are more concerned with fundamentals and governance than observers give them credit for. Thus, good governance will ultimately be rewarded.

Second, while a great deal of speculation does take place on the market, it is driven by institutional investors, not individuals. Therefore, current government policy - which blames individuals for speculation and attempts to curb it by encouraging institutional investors who will, it is assumed, take a longer-term perspective-is unlikely to be successful.

Third, policymakers in the field of corporate governance should not worry so much about the small investor. ${ }^{14} \mathrm{He}$ is not a major source of funds, and in any case can be no more than a price taker. Contrary to government fears, a market downswing will not bring 100 million angry citizens into the street protesting the loss of their life savings. It would, of course, create massive discontent among a small elite of the wealthy and powerful, which may be an equally good explanation of government fear of a falling market. But it is not the same thing.

\section{Banks}

Capital structure can be a source of oversight: a corporation with dispersed ownership and low leverage is one in which the managers have a great deal of slack. Conversely, high debt levels can mean close monitoring by creditors. While creditors monitor in their own interests, and not those of the shareholders, their interests are sufficiently congruent most of the time to be beneficial to shareholders.

In many economies, banks play a critical role in corporate governance (Gray 1997). Unlike small shareholders, they are both able and willing to monitor the financial health of their debtors. Moreover, academic research suggests that investment financed with bank debt tends to be more efficient than investment financed with retained earnings, probably because the former must be justified to a possibly skeptical third party, whereas management's use of retained earnings is suhiert to nn nversioht (Iencen loek 


\section{Donald C. Clarke}

Banks may also be sufficiently dubious of a prospective borrower's financial health to refuse to lend at all, thus hastening the departure of a poorly run or otherwise inefficient company from the economy. And they may themselves be major shareholders, as in Germany or Japan, ${ }^{15}$ although not in the United States (Roe 1994).

Chinese banks, however, have historically been incapable of playing this monitoring role. This is because they lacked both the ability to monitor and the incentive to do so.

As discussed above, the traditional role of banks was that of cashiers for the state. Even after the reforms of the 1980s, lending decisions were based on political criteria and the perceived needs of SOE borrowers, not on the prospect of the loan being repaid from the proceeds of whatever project it was used to fund (Su 2000).

Bankers thus did not have the tools to understand whether a loan was being put to good use or not; that was not a question with which they were intended to concern themselves, and the accounting system at the time would not have provided an answer. ${ }^{16}$ They were simply to supply the money when ordered to do so. Nor did they need to worry about defaults; profit was simply not the objective and played no significant part in the evaluation of bank executives.

The result of all this is that banks have lacked what might be called a culture of monitoring (Chow and Fung 1998; Tian and Lau 2001). The very lack of a monitoring culture in banks has shaped corporate law significantly, as the state has tried to do through corporate law what the banks seem incapable of doing for themselves: protecting their interests as creditors. ${ }^{17}$ In other words, far from enlisting the help of active banks in monitoring corporations, China's corporate law sees them as passive victims that need protection.

Recent scholarship suggests that the value of bank monitoring in Germany and Japan is much less than was supposed during the 1980s, when German and Japanese corporate governance models were in vogue. ${ }^{18}$ If German and Japanese banks find it hard to monitor effectively, it is unrealistic to expect Chinese banks to manage. And because banks are still often required to lend for political reasons, the result is that corporate management has been subject to the discipline neither of the credit market when seeking a loan nor of lender monitoring after obtaining it.

\section{Asset management companies}

A possible substitute for banks as monitors has been the four asset management companies (AMCs), one corresponding to each of the Big Four banks, created in 1999 as part of a plan to recapitalize the state banking sector. The AMCs, organized as wholly state-owned non-bank financial institutions in corporate form owned (it appears) by the Ministry of Finance (MOF), were capitalized at 10 billion yuan each by the MOF. They
The role of non-legal institutions in Chinese corporate governance

then purchased, at face value, some 1.4 trillion yuan in non-performing loans from their corresponding banks, paying with ten-year bonds that they issued with a soft guarantee from the MOF. The intent was that the AMCs would then use their position as creditors (or as owners via debt-for-equity swaps) to force restructuring on the debtor enterprises. ${ }^{19}$ The AMC could then sell its interest in the now valuable enterprise to an outside investor.

Unfortunately, some-not all-of the same problems that prevented banks from being effective monitors have also stymied the AMCs, most notably the political clout of the debtor enterprises and their government owners (Studwell 2002: 259-260; Tenev and Zhang 2002: 63-64). An account of the efforts of one of them, Huarong, is worth quoting in full:

Monkey King Group (MKG), an industrial conglomerate from Yichang city in Hubei province, is one of the country's 512 key SOEs and one of the big SOEs to benefit from the debt-for-equity swap scheme put in place by the central government. In August 2000, China Huarong Asset Management Company bought 622 million RMB in MKG debt from The Industrial and Commercial Bank of China (ICBC). Since then, Huarong, the main creditor of the group, has been unable to press $M K G$ into a drastic restructuring plan. On the contrary, with the approval of Yichang city officials, in December 2000, MKG started a huge asset stripping manoeuvre that has shrunk group assets from 2.42 billion RMB to 371 million RMB, according to Huarong. MKG then petitioned for bankruptcy to escape a restructuring plan coming from its main creditor Huarong, without informing the board of directors of its listed company. Last March, Huarong publicly questioned the fairness of the liquidation committee appointed by Yichang court, as it was composed only of representatives of local government agencies.

(OECD 2002: 180, citing Miller 2001)

\section{Board of directors and board of supervisors}

A key institution of corporate governance is an internal oversight body such as a board of directors and, in China, a board of supervisors. These function, ideally, as a committee of the shareholders, and represent an attempt to overcome the costliness of monitoring by individual shareholders. Needless to say, there are many obstacles to the effective functioning of the board in this way-management typically has a great deal of control over the election process, and thus can generally seat its preferred candidates when shareholding is widely dispersed (Bebchuk 2007).

\section{Independent directors}

Chinese corporate governance has high expectations for independent directors. In 2001, the CSRC issued a "Guidance Opinion" (zhidao yijian) calling 
for listed companies to have a one-third independent board by mid-2003, and virtually all have complied at least in form. ${ }^{20}$

Despite the attention devoted to independent directors, it is unlikely that they can play their hoped-for role. An important reason is that the Chinese independent director system does not provide for a good way of policing independence to ensure that it is genuine. The CSRC must vet candidates, it is true, but as a practical matter the CSRC cannot possibly know both before election and on a continuing basis whether directors meet the criteria, both in name and in fact, for independence.

Consider, by way of contrast, the American system of disinterested directors. In making their votes highly desirable as a way of insulating conflict-of-interest transactions from substantive scrutiny, corporate law gives them a role that requires, in case of dispute, examination of the degree to which they actually were disinterested in the transaction in question. Chinese corporate law-in this sense like the New York Stock Exchange rules on independent directors, among others-simply requires that directors meet some criterion of independence, but fails to provide a meaningful policing mechanism. ${ }^{21}$

The votes of independent directors in Chinese corporate law have no special significance. The CSRC has indeed attempted to legislate in this area by stating, in its Several Provisions on Strengthening the Rights and Interests of Public Shareholders (CSRC 2004), that several matters must be approved by a majority of independent directors. Yet what will happen if they are not? The CSRC's authority to legislate such substantive corporate governance rules is uncertain. It cannot nullify a material transaction between a firm and an affiliate that was undertaken without the desired independent director approval, nor can it make rules giving shareholders grounds to sue for the same event.

In short, if independent directors are an institutional solution to vertical agency problems, China has gone only half way: it has provided the form of the institution, but has not provided the accompanying institutions that would give it life and significance.

\section{Board of supervisors}

Another potential institutional solution to the agency problem is the board of supervisors (jianshi hui). ${ }^{22}$ Chinese commentators often compare China's two-tier governance model to Germany's, where the law mandates a dualboard system for large publicly held corporations, but the similarities in fact are few. In Germany, each corporation has an elected supervisory board (Aufsichtsrat), which appoints a managing board (Vorstand) composed of senior managers. The supervisory board's job is to oversee the management of the company (Law on Stock Corporations $\S 111(1)$ ), and its major powers are the power to appoint and dismiss members of the managing board and the power to represent the company in its dealings with members of the management board (Oppenhoff and Verhoeven 2003: $\S 24.03$ ). The law explicitly allocates managerial power to the managing board (Law on Stock Corporations $\S 76(1)$ ).

While German law gives real power to the supervisory board, the Company Law of China expects that the board of supervisors will perform a supervisory role essentially by simply saying that it will, without actually giving the board any significant powers or providing structurally for its independence from those it supervises. Like the board of directors, the board of supervisors is elected by shareholders. ${ }^{23}$ There is no reason to expect that the interests that dominate director voting will fail to dominate supervisor voting. Moreover, in enterprises dominated by state ownership, supervisors are enterprise employees and are subordinate to the enterprise chief. Not surprisingly, they bend to his wishes (Jiang 2001; Gao 2002: 9; Wang and Feng 2002: 120).

As a result of these problems, the board of supervisors appears to play no important role in corporate governance in China. Indeed, the impetus behind the independent director drive has been the hope that they will play the monitoring role that the board of supervisors has been unable to play.

\section{The large shareholder as monitor: the state}

Large shareholders can often be reasonably effective in monitoring corporate managers; if they do not abuse their control rights, their efforts benefit small shareholders as well. In China, the dominant shareholder in listed companies is often a state body. Commentators often point to this absence of an ultimate human principal with rights to residual earnings at the top of the chain of agents as the reason for ineffective monitoring. But many nonprofit organizations operate successfully without such an ultimate principal. On the other hand, it is clear that in fact the state often is ineffective; it is not collective action problems that prevent effective shareholder monitoring, since there is a large and possibly sole shareholder, but rather organizational problems internal to that shareholder. The result is the phenomenon of the "absent owner" (suoyouzhe quewei). What are these problems?

First, the state often simply does not want to encourage the profit-maximizing behavior that minority shareholders value. But even when it does, it suffers significant disabilities as a monitor.

It may, for example, have inconsistent and incommensurable goals, such as full urban employment, efficient operations, and a bar on foreign ownership or control for reasons of national security. But even if the state as principal had mutually consistent and easily measurable goals, its agentsthe monitors of the enterprise managers--might not monitor well for those goals. First, the monitoring individuals may well be locally employed and salaried, while the formal ownership of the shares is lodged in a higher level of government. A monitor responsible to local government will not object to corporate policies such as high employment that are beneficial to local government at the expense of the central state shareholder. Second, a 
monitor working in a government agency may be less able to distinguish good from bad corporate policy than a monitor in a business-oriented institutional shareholder. ${ }^{24}$ Third, an individual monitoring on behalf of the state is much less likely to have someone at some point above him in the chain of command making a strong demand for good corporate performance in companies held by the state.

Finally, the devolution of managerial authority has occurred in tandem with economic reform measures that have legalized new forms of trade and new privately controlled entities to which stripped assets can, by means of controlled transactions, be transferred. The complexity of property relations and ownership forms has outstripped the state's capacity to monitor, which remains designed for the simple structures of an earlier day, when private ownership of significant property was not allowed, and transfers between enterprises were physical and not financial (Ding 2000).

\section{Shareholder coalescence devices}

Corporate governance is enhanced by institutions that allow for the coalescence of shareholders and thus potentially overcome the monitoring problems of the small shareholder (Roe 2004: 10). Such institutions include proxy fights and takeovers: while it may not pay a small shareholder to figure out how the company could be run better, it may pay an outsider to do so if he can buy up the shares and reap the benefit. This set of institutions has its own costs, of course: if concentrated shareholding were free, we would never see dispersed shareholding.

So far, at least, there is no hostile takeover activity to speak of in China. When listed companies were takeover targets, this was typically so that the acquirer could obtain a "backdoor" listing and thus have access to the stock market without having to gain approval itself. In addition, recall that typically only one-third of listed company stock is actually available as circulating stock, with the rest held as state or legal-person shares by a small number of shareholders. If they are contented with management, they will not sell to a hostile bidder. If they are not contented with management, they have the power to change it. In short, in the great majority of listed companies, a particular management team would not be in place if it were not performing to the satisfaction of the holders of a majority of shares.

Even if more shares were available on the market, one study found a negative correlation between performance and the proportion of shares traded on the market (Chen 2001: 68-69). This suggests that management does not perceive a large number of circulating shares as a threat to its tenure.

\section{Management compensation arrangements}

A common method of tying management incentives to shareholder interests is through compensation arrangements, such as those that tie salary to stock price performance. Among those in China who recognize that the separation of ownership from control is an unavoidable problem, a frequently mooted solution is simply to make managers more like owners by giving them an equity stake in the firm. For example, Yang and Zhang (2000: 18) suggest letting large stockholders take on management roles and letting some managers be large stockholders. The first part of this solution is unexceptionable if understood to mean that corporate governance policy should not fear the role that can be played by large shareholders with an interest to protect.

The second prong of their solution is more problematic. If directors and other senior officers are not rich enough to own significant amounts of stock, should stock in such large amounts as to be significant be simply given to them? It might provide directors with more incentives, but would also involve a shockingly immense transfer of wealth to them.

Even a tiny percentage ownership stake in a listed company is a huge amount, given the amounts of money involved. A commonly suggested target for management ownership is 1 percent. If we value listed companies conservatively-at only the value of circulating shares-the total comes to about US\$731 billion, or about US\$495 million for each of the 1,477 listed companies. $^{25}$ To give management 1 percent means handing over on average about US $\$ 4.95$ million. Surely a reduction in agency costs can be purchased more cheaply.

Moreover, such a small stake cannot be expected to have an appreciable effect on management incentives. A manager holding a 1 percent interest who expropriates US\$100 from shareholders will still net US\$99. Yang and Zhang (2000) themselves note that a CEO with a 25 percent interest in the company still has a large incentive to engage in expropriating transactions. Yet giving CEOs a big enough stake to make a real difference--say, 50 percent-is not just unrealistic and unjust, but also unnecessary. Other institutions manage to procure reasonable performance from their agents for less than this, and there is no reason why Chinese corporations cannot manage to do so as well.

\section{Gatekeepers (1): lawyers and accountants}

Persons and institutions involved in information distribution and gatekeeping-including lawyers, accountants, securities analysts, underwriters, and the financial press-play an important role in corporate governance in many jurisdictions. The theory is that because they are repeat players whose income depends on reputation, the gains from maintaining that reputation will outweigh the gains from defecting and cooperating in fraud and mismanagement. Corporate insiders, it is thought, have the opposite set of incentives (Gilson and Kraakman 1984: 595-607). ${ }^{26}$

To perform their function, all of these must of course be appropriately motivated. If lawyers and accountants bear no responsibility for their opinions, 
one cannot expect them to press their corporate clients to correct a state of affairs that damages shareholders. Similarly, one cannot expect much from the financial press if the rewards for providing accurate information are less than the rewards for not doing so.

Neither the legal nor the accounting professions in China are yet well equipped to play an effective gatekeeper role. The Securities and Exchange Commission has been able to farm out much of its supervisory burden to both professions in the United States because they are capable of handling the task. By contrast, China's lawyers are few in number and, like its accountants, not trained to handle complex financial matters. ${ }^{27}$ The law schools do not teach such topics, and the modern legal profession has not yet accumulated enough experience to enable juniors to learn from seniors on the job.

The position of the accounting profession is even worse. ${ }^{28}$ China suffers from an acute shortage of qualified accountants (Jopson 2006). A 2001 study of 32 randomly selected audit reports found "gravely inaccurate errors" in

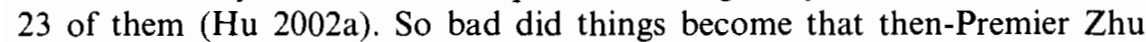
Rongji called for foreign auditing firms to conduct supplemental audits of all listed firms in China (Hu 2002b; McGregor 2002). And the securities industry seems almost beyond redemption: a CSRC investigation revealed that in the notorious market manipulation scheme of Lü Liang, 125 securities firms actively assisted him (Walter and Howie 2003: 156-157).

As suggested above, lawyers and accountants cannot be expected to play a gatekeeping role if they bear little or no penalty for failing to do so. The system in China imposes few such penalties. While law firms and accounting firms may occasionally be sanctioned by the CSRC, I know of no lawsuits by misled investors against either. And firms seeking listings continue to use the same group of law and accounting firms without suffering any apparent penalty in the market (Irvin 2005)

\section{Gatekeepers (2): the financial press}

A critical part of a healthy corporate governance system is information that is both demanded by and accessible to investors and other participants in the corporate enterprise. And a key institution in both creating or assembling information and making it accessible is an independent and competitive press (Black 2001: 798-799).

The story of China's financial press in terms of these desiderata is a mixed one. On the one hand, the last several years have seen a mushrooming of newspaper, journals, and websites purveying information about economic and financial issues. In addition to the most well-known journal, Caijing ("Finance and Economy"), these media include 21st Century Economic Report (21 Shiji Jingji Baodao), China Securities News (Zhongguo Zhengquan Bao), Economic Daily (Jingji Ribao), Securities Times (Zhengquan Shibao), and New Fortune (Xin Caifu). There is no doubt that these media compete with each other, and Caijing in particular has produced
some solid journalism with several exposés. ${ }^{29}$

On the other hand, these media all owe their existence to some kind of formal or informal government affiliation; one cannot simply decide to start a newspaper in China. Beyond the possible inhibiting influence of ownership ties, it must further be remembered that the state insists in principle on control over all information. ${ }^{30}$ This control is a cornerstone of the Communist Party's system of political control and is unlikely to disappear before the Party itself.

In the early days of China's financial press, it was regulated quite strictly by the CSRC--in the interests not of accuracy but of stability ( $\mathrm{Hu} \mathrm{2003}$. 64). Following an exposé by Caijing of a scandal involving massive market manipulation by investment funds (Ping and $\mathrm{Li} 2000$ ), however, the CSRC under Zhou Xiaochuan began to appreciate the positive role that could be played by the financial press and loosened the reins. This led to Caijing's most famous scoop, the exposure of fraudulent dealings at Guangxia Corporation of Yinchuan (also known as Yinguangxia).

At present, however, Caijing's successes are more exceptional than typical, and financial reporting remains hobbled in significant ways. Objective reporting is hampered by corruption: favorable press coverage can often be obtained, and unfavorable coverage suppressed, for a price (Liebman 2005: 39-40). Many financial reporters lack training in the field, resulting in superficial coverage. Journals that publish unwelcome stories may find themselves sued for libel (Liebman 2006: 69).

The picture is not completely bleak-in a recent libel case based on unfavorable press coverage, the court found that journalists should be immune from suit if their reporting is backed by a source that is reasonable and credible and not based simply on rumors. ${ }^{31}$ Nevertheless, the overwhelming fact is continuing political restraints on what may or may not be published, a fact that is known and to some degree accepted by all, or at least most, within the industry.

\section{Conclusion}

This chapter has examined the non-state institutional environment for Chinese corporate governance. Several institutional approaches to corporate governance are possible, chief among them an ownership approach, a shareholder rights approach, and a market monitoring approach. A given jurisdiction will typically display a mix.

The institutions of ownership can play a monitoring function when there is concentrated ownership, and it pays the dominant shareholder to expend resources in monitoring because it will reap all or most of the benefit. This kind of monitoring need rely neither on minority shareholder rights nor on market signals in order to discipline management; the owner is already in charge and does not need the help of courts, and it can receive from its own analysis the signals that would otherwise be transmitted by the market. 
The ownership approach does not, however, come free. Holders of large blocks of shares are less able to enjoy the benefits of a diversified riskreducing portfolio. Companies too large for any single owner to control cannot use this governance method. And to the extent that the owner undertakes its own analysis instead of relying on market signals, it must expend resources instead of free riding on the activity of others.

Finally, while concentrated ownership can mitigate one set of agency costs-vertical, between managers and shareholders as a body-it can exacerbate another set-horizontal, between dominant shareholders and minority shareholders. As the former decrease, the latter may increase. Which effect will outweigh the other cannot be known a priori.

The shareholder rights approach attempts to solve the problems of minority shareholders who cannot avail themselves of ownership rights-not only do they not have the rights of owners, but they also do not have the same incentives as owners. If minority shareholders can enlist the aid of the legal system at an acceptable cost, however (including the cost of informing themselves), they can protect their interests and both correct and deter management misbehavior.

Like the ownership approach, however, this approach has its characteristic costs. The more power minority shareholders have to protect their legitimate rights, the more power they have to pursue illegitimate claims as well for their nuisance value. A corporation whose shareholders enjoy the fullest complement of rights is a paralyzed corporation. People rationally choose to hold a security that does not grant all the rights they might like for themselves because they know that other investors are similarly constrained. The key, therefore, is to strike the right balance.

Where that balance should be struck, however, will differ across jurisdictions, because the availability of substitutes will differ. If there is a good substitute for minority shareholder rights, then there is little reason to pay the cost of an extensive panoply of rights because the marginal benefit thereby purchased will be small.

This consideration leads to the third approach to corporate governance: the market monitoring approach. As discussed above, a firm operates in a number of markets that impose objective constraints on its management. At the most obvious level, the stock market and not management has the final word on the appropriate value of a company's stock. When markets are functioning well, monitoring is much simpler. If stockholders wish to judge whether the CEO's salary is excessive, they can look at salaries in comparable companies.

Needless to say, knowing that a CEO is paid too much is not the same as being able to do something about it, so the existence of a managerial labor market is not a complete corporate governance solution. But if the stock market shares this knowledge, then the stock price is discounted accordingly, and those who buy after this knowledge is incorporated into the stock price are not harmed bv it. Thus. the small investor can free-ride off the valuation efforts of market professionals, and to the extent that the stock market effectively disciplines managers (and dominant shareholders if management does their bidding), the small investor needs no special protections.

Where does China fit into all this? For all the attention it receives, the shareholder rights approach-indeed, any approach that relies upon formal legal institutions-cannot be expected to form the mainstay of an effective corporate governance regime. The courts have neither the power nor the inclination to play a major role, and government agencies such as the CSRC do not have the resources to serve as a substitute. ${ }^{32}$

Nor does the ownership approach hold out much hope. At present, dominant shareholders seem either to abuse their control or to fail to exercise it entirely. There are two possible ways in which these problems could be remedied. The state could improve its internal management system so that it became a more effective monitor in the companies it dominated. Such a reform is imaginable, but fails to address the issue of abuse of control. The control of abuses rests ultimately, like the shareholder rights approach, on legal institutions-and as argued above, legal institutions are a weak reed on which to rely.

Unfortunately, the best available substitute approach, that of market monitoring, is disfavored by the state. The Chinese state prefers direct regulation by government agencies first, and indirect regulation by private litigation in the state's courts next. Regulation by the uncontrolled institutions of the market comes a distant third, and indeed it is hard to find such institutions in China. The stock markets are creatures of the state and exist only upon its sufferance; securities firms are established and owned by various governmental bodies; banks are either directly owned or else highly controlled by governmental bodies; the financial press is subject to significant state influence, both through ownership channels and through the state's pervasive regulation of the media.

In a state with limited administrative resources, it would make sense to rely as far as possible on the contributions of non-state actors. But Chinese corporate governance institutions are tilted toward the legal because the government generally suspects the institutions of the market and civil society in general. It wants rules, not incentive structures. There is an excessive emphasis on getting the rules right, and an inadequate attention to institutions that could be flexible in creating and enforcing rules as the situation warranted.

The Asian financial crisis of 1997-1998 gave governments of the region good reason to be concerned with corporate governance issues. Weak corporate governance, insofar as it saps the confidence of investors in their ability to forestall managerial expropriation, can exacerbate such crises (Johnson et al. 2000)..$^{33}$ When times are good, insiders refrain from excessive expropriation of outsiders because they desire future financing and care about their reputation. As future prospects deteriorate, however, an endgame situation appears, and insiders step up their expropriation. This is 


\section{Donald C. Clarke}

perceived, and perhaps even foreseen, by investors, who attempt to liquidate their positions as soon as possible (calling loans that can be called in the case of banks and selling stock in the case of equity investors). This pushes the firm nearer to collapse and the stock price further down. As the lack of sound corporate governance is a national problem, there are no attractive alternative investments domestically, so the withdrawn capital flees, exacerbating the collapse of the currency as it goes.

That corporate governance is a matter of public as well as private concern, however, does not mean that the only or best solution to corporate governance problems is a public one initiated by the state. An important part of any solution to China's corporate governance problems, given its current set of administrative and legal institution, lies not in the state's actively beefing up those institutions, but simply in its relaxing its hostility to civil society institutions and understanding that corporate governance is too important a matter to be left solely to the state.

\section{Notes}

1 A partial exception is Liebman and Milhaupt (2007)-partial because the authors examine sanctions imposed by China's stock exchanges, which are quasigovernmental bodies.

2 See, for example, $\mathrm{Xu}$ and $\mathrm{Li}$ (2001), who cite with approval tests developed in U.S. law such as "interest or expectancy," "line of business," and "fairness."

3 See, for example, Elster (1986), who questions the applicability of the biological analogy to economic activity on the grounds that the economic environment changes rapidly relative to the speed with which inefficient firms are eliminated from competition, and that therefore at any given time we are likely to observe efficient and inefficient firms coexisting.

4 Listed company shares in China were traditionally classified as circulating or non-circulating. Circulating shares, as the name suggests, are available for trading on the public markets. Until very recently, however, they typically represented only one-quarter to one-third of the total share capital of listed companies. The rest was in the form of non-circulating shares that, with minor exceptions, could be held only by state entities (state shares) or other corporate entities (legal person shares). Such shares are highly illiquid. For a fuller account of share types, see Walter and Howie (2003: 71-87). At present, reforms are underway to gradually convert all non-circulating shares to circulating shares. Many shares have been reclassified as "circulating" shares, although some are still subject to lock-ups and may not yet be freely sold. At the time of this writing (September 2007), the website of the China Securities Regulatory Commission (CSRC) shows the market capitalization of circulating shares to be just one-third the value of total market capitalization (valuing all shares as circulating shares), showing that it defines as non-circulating about two-thirds of the outstanding shares of listed companies.

5 Chen and Xiong (2002) found that the non-tradable state-owned shares and legal-person shares in China on average had a $70-80$ percent illiquidity discount when they were traded on informal markets. Walter and Howie (2003: 186) also present data for sales of legal-person shares in three companies, showing discounts of between 76 and 83 percent. For more extended discussions of how to value listed companies, see Green (2003b) and Walter and Howie (2003: 188-189).
The role of non-legal institutions in Chinese corporate governance

6 I write this, of course, at the risk of looking very foolish by the time this chapter appears in print, since by then we will know whether it was a bubble or not.

7 In the words of Fraser Howie, a long-time observer of the Chinese market quoted in the story, "All reality has been suspended in China." (Dyer 2007a.)

8 Non-financial institutions include households, enterprises, and government agencies.

9 Although the authors do not specify, they are probably referring to the mean PE ratio. A better number, because not skewed by extremes, would be the median PE ratio; it might be lower.

10 Company Law (1993), art. 137. The 1993 version of the Company Law was amended in 2005, effective as of 2006 (Company Law 2005). Article 137 of the 1993 Company Law was removed in the 2005 revisions to the Company Law and the Securities Law (Securities Law 2005). Article 13 of that law required the ability to earn profits continuously and a healthy financial state, but did not specify the three-year rule.

11 For example, in the 18 months from mid-2004 to the end of 2006, the number of stock accounts rose from 71.5 million to 78.5 million. In the next six months, the number shot up to 107 million (CSRC website, 1 September 2007). On a single day-28 May 2007-investors opened 385,000 new accounts (Dyer 2007b). As noted in the text above, however, this is not the same as saying that 385,000 new investors came into the market.

12 For a full analysis of the investor community, see Green (2003b: ch. 4) and Walter and Howie (2003: ch. 7).

13 A subsequent study finds a turnover velocity of 509 percent in 2000 (Chang and Wong 2003); see also $\mathrm{Hu}(2002 \mathrm{c})$.

14 This is the advice for developing and transition economies generally of Berglöf and von Thadden (1999).

15 For a discussion of various views on the "main bank" system, see Milhaupt (2001).

16 The Chinese accounting system in the pre-reform era was typical for a planned economy: it was about matching sources to uses to monitor the spending of funds as the funder intended. It was not about matching revenues to expenditures to ensure that investments were profitable. See generally Huang and Ma (2001: 25-28).

17 Of course, every mature legal system provides a range of protection for corporate creditors; in the United States, such protection is accomplished largely through state law restrictions on corporate distributions and state and federal rules on fraudulent transfers. In China, however, corporate law protection is viewed as necessary to save creditors from their own misguided lending decisions.

18 On the softness of German and Japanese bank monitoring, see Shleifer and Vishny (1997: 773) and the sources cited in La Porta et al. (2000: 17-18).

19 For a fuller description, see Asian Development Bank (2003: 58-60) and OECD (2002: 179-181).

20 For a full treatment of independent directors in China, see Clarke (2006), on which much of this discussion is based.

21 I discuss the differences among independent, outside, and disinterested directors in Clarke (2007a).

22 I treat the board of supervisors at greater length in Clarke (2006: 173-175)

23 The Company Law provides that up to one-third of the supervisors shall be elected by the employees of the company (Company Law 1993: art. 124; Company Law 2005: art. 118), but such elections are dominated by management and the supervisors so elected cannot provide an independent check.

24 For a fuller discussion, see Qi et al. (2000: 594-595); see also Mar and Young (2001: 282), who state that "although Chinese SOEs [(state-owned enterprises)] 
have concentrated ownership (i.e., the state) the potential positive effect of such an arrangement is absent because of the dispersal of state representation. ... In short, many SOEs are simply monitored inadequately or ineffectively."

25 The data are as of 30 June 2007 (CSRC website, I September 2007).

26 But see Coffee (2002), who argues that reputation is not as effective a policing mechanism as is commonly assumed.

27 On the capabilities of the Chinese legal profession, see generally Lubman (1999: 157) and Peerenboom (2002: 343-393). On the accounting profession, see Tenev and Zhang (2002: 120-123).

28 See generally Irvin (2005), to which much of the discussion and the citations in this subsection are owed.

29 On Caijing and its editor, Hu Shuli, see Chandler (2001).

30 For an overview of Party and government controls over the media, see Liebman (2005: 41-65).

31 The case in question pitted the Guangzhou Huaqiao Real Estate Development Company against the journal China Reform. Excerpts from the text of the judgment as well as commentary by prominent attorney Pu Zhiqiang, who appeared for the defendants, can be found at www.epochtimes.com/gb/4/10/18/n694419.htm.

32 There is not space here to make this argument in detail; I do so in another unpublished paper (Clarke 2007b). Nicholas Howson's chapter in this volume lists several interesting cases bearing on the issue of court enforcement of shareholder rights, but in only three (perhaps four-one case report is unclear) of those cases can courts be said to have found a breach of duty to shareholders.

33 According to Johnson and his colleagues, governance variables such as investor protection indices and the quality of law enforcement are powerful predictors of the extent of market declines during the Asian financial crises, and explain the decline better than the macroeconomic variables that have been the usual focus of the policy debate.

\section{Bibliography}

AFP [Agence France-Presse] (2006) "China to Complete State-Share Reforms This Year," China Daily, internet edn, 24 April.

Allen, Franklin, Jun Qian, and Meijun Qian (2002) "Law, finance, and economic growth in China," Wharton Financial Institutions Center working papers series, No. 02-44 (23 December 2002). Online at http://fic.wharton.upenn.edu/fic/papers/02/0244.pdf. (2005) "Law, finance, and economic growth in China," Journal of Financial Economics 77: 57-116.

Asian Development Bank (2003) "Asian Development Bank, private sector assessment: People's Republic of China."

Bai, Chong-En et al. (2003) "Corporate governance and market valuation in China," William Davidson Institute, working paper No. 564. Online at http://ssm.com/ abstract $=393440$.

Bebchuk, Lucien (2007) "The myth of the shareholder franchise," Virginia Law Review 93: 675-732.

Beijing Modern Business News (2005) "7000 wan gumin qunian meihu junping kuisun 2045 yuan 70 million stock investors lost 2045 yuan per person on average last year]," Beijing Xiandai Shangbao [Beijing Modern Business News] (5 January).

Berglöf, Erik and Ernst-Ludwig von Thadden (1999) "The changing corporate governance paradigm: implications for transition and developing countries," unpublished manuscript (June)
Black, Bernard S. (2001) "The legal and institutional preconditions of strong securities markets," UCLA Law Review 48: 781-855.

Chandler, Clay (2001) "China moves: business magazine thrives by crossing the party line," Washington Post, E01 (22 March).

Chang, Eric C. and Sonia M.L. Wong (2003) "Political control and performance in China's listed firms 25" (March). Available at http://www.hiebs.hku.hk/working_papers. asp?ID $=89$.

Chen, Charles J.P., Shimin Chen and Xijia Su (1999) "Is accounting information value relevant in the emerging Chinese stock market?" Available at http://ssrn. com/abstract $=167353$.

Chen, Jian (2001) "Ownership structure as corporate governance mechanism: evidence from Chinese listed companies," Economics of Planning 34: 53-72.

Chen, Zhiwu and Peng Xiong (2002) "The Illiquidity Discount in China," International Center for Financial Research, Yale University.

Chen, Zhiwu, Peng Xiong and Lin Yang (2000) "Faren gu paimai shizheng yanjiu [Empirical research into auctions of legal person shares]." On file with author.

Chow, Clement Kong Wing and Michael Ka Yiu Fung (1998) "Ownership structure, lending bias, and liquidity constraints: evidence from Shanghai's manufacturing sector," Journal of Comparative Economics 26: 301-316.

Clarke, Donald C. (2006) "The independent director in Chinese corporate governance," Delaware Journal of Corporate Law 31: 125-228.

(2007a) "Three Concepts of the Independent Director," Delaware Journal of Corporate Law 32: 73-211.

- (2007b) "Corporate governance in China: dilemmas of reform and the institutional environment" (unpublished working paper, 2007).

Coffee, John C., Jr. (2002) "Understanding Enron: it's about the gatekeepers, stupid," The Business Lawyer 57: 1403-20.

Company Law (1993) "Zhonghua renmin gongheguo gongsi fa [Company Law of the People's Republic of China]" (effective 1 July 1994).

Company Law (2005) "Zhonghua renmin gongheguo gongsi fa [Company law of the People's Republic of China]" (as amended 27 October 2005, effective 1 January 2006).

CSRC [China Securities Regulatory Commission] (2004) "Guanyu fabu 'guanyu jiaqiang shehui gongzhong gu gudong quanyi de ruogan guiding' de tongzhi [Notice on the Issuance of the 'Several provisions on on strengthening the rights and interests of public shareholders']", Zheng Jian Fa (2004) No. 18 (7 December).

CSRC [China Securities Regulatory Commission] website. Available at http://www csrc.gov.cn (accessed various times).

Denis, Diane K. and John J. McConnell (2003) "International corporate governance," Journal of Financial and Quantitative Analysis 38: 1-36.

Ding, X.L. (2000) "The illicit asset stripping of Chinese state firms," China Journal 43: $1-28$.

Durnev, Art, Kan Li, Randall Morck and Bernard Yin Yeung (2004) "Capital markets and capital allocation: implications for economies in transition," Economics of Transition, 12(4): 593-634 (December).

Dyer, Geoff (2007a) "Chinese stock market bigger than Japan's," Financial Times (29 August).

(2007b) "Share trading accounts in China hit 100M," Financial Times (29 May). 


\section{Donald C. Clarke}

Elster, Jon (ed.) (1986) Rational Choice, New York: New York University Press.

Fox, Merritt, Artyom Durnev, Randall Morck, and Bernard Yeung (2003) "Law, share price accuracy, and economic performance: the new evidence," Michigan Law Review, 102: 331-386

Gao, Yong (2002) "Duli dongshi zhidu yu shangshi gongsi zhili [The Independent Director System and Corporate Governance in Listed Companies]", Jingii Tizhi Gaige [Economic System Reform] 1: 8-12.

Gilson, Ronald J. and Reinier H. Kraakman (1984) "The mechanisms of market efficiency," Virginia Law Review 70(4): 545-644.

Gray, Cheryl (1997) "Creditors' crucial role in corporate governance," Finance and Development 34: 29-32.

Green, Stephen (2003a) "China's stockmarket: eight myths and some reasons to be optimistic," The China Project, Royal Institute of International Affairs and Cambridge University (February).

- (2003b) "Better than a casino: some good news from the frontline of China's capital market reforms," Royal Institute of International Affairs, Asia Programme, working paper No. 6 .

Hong Kong Stock Exchange (2004) "Institutional investors in mainland China" (January). Available at http://www.hkex.com.hk/research/rpapers/IIMC.pdf

$\mathrm{Hu}$, Bei (2002a) "Mainland companies are reeling from a year of financial scandals during which the audacity of corporate wrongdoers has put their Western counterparts to shame," South China Morning Post, 1 (26 March).

(2002b) "Tough audit rules eased after outcry from interest groups," South China Morning Post, B3 (2 March).

- (2002c) "Exposure to stocks unhealthy; trading mostly speculative," South China Morning Post, B4 (16 April).

Hu, Shuli (2003) "Let there be more light," China Economic Quarterly 7: 64-66.

Huang, Allen and Ronald Ma (2001) Accounting in China in Transition: 1949-2000, World Scientific Publishing Company Incorporated.

Irvin, Brent (2005) "The ecology of corporate governance in China," unpublished manuscript.

Jensen, Michael and Curtis J. Meckling (1976) "Theory of the firm: managerial behavior, agency costs, and ownership structure," Journal of Financial Economics 3: 305-360.

Jensen, Michael C. (1986) "Agency cost of free cash flow, corporate finance and takeovers," American Economic Review 76: 323-329.

Jiang, Qiangui (2001) "Gongsi zhili yu guoyu qiye gaige [Corporate governance and state-owned enterprise reform]," Zhongguo Zhengquan Bao [China Securities News] internet edn. (12 June).

Johnson, Simon et al. (2000) "Corporate governance in the Asian financial crisis," Journal of Financial Economics 58: 141-186.

Jopson, Barney (2006) "Beijing in overseas accountancy deal," Financial Times, internet edn. (25 July).

Kroeber, Arthur (2007) "China stock frenzy," Financial Times (2 July).

La Porta, Rafael et al. (1998) "Corporate ownership around the world," Harvard Institute of Economics, research paper No. 1840 (August 1998). Online at http:// ssrn.com/abstract $=103130$.

(2000), "Investor protection and corporate governance," Journal of Financial Economics 58: 3-27.
The role of non-legal institutions in Chinese corporate governance

Lardy, Nicholas R. (1998) China's Unfinished Economics Revolution, Washington, DC: Brookings Institution Press.

Law on Stock Corporations (Germany). Aktiengesselschaften [Law on Stock Corporations] (as amended 28 October 1994).

Liebman, Bejamin (2005) "Watchdog or demagogue? The media in the Chinese legal system," Columbia Law Review 105: 1-157.

(2006) "Innovation through intimidation: an empirical account of defamation litigation in China," Havard International Law Journal 47: 33-177.

Liebman, Benjamin L. and Curtis J. Milhaupt (2007) "Reputational sanctions in China's securities market," Columbia Law and Economics working paper. Available at http://ssrn.com/abstract=999698.

Lubman, Stanley (1999) Bird in a Cage: Legal Reform in China After Mao, Palo Alto: Stanford University Press.

McGregor, Richard (2002) "Creative Chinese accounting creates work for Andersen," Financial Times, 20 (28 January).

Milhaupt, Curtis J. (2001) "On the (fleeting) existence of the main bank system and other Japanese economic institutions," Columbia Law School, Center for Law and Economic Studies, working paper No. 194 (9 November 2001). Online at http:// papers.ssrn.com/abstract $=290283$.

Miller, Matthew (2001) "Real monkey business," South China Morning Post, Business Post, 14 (29 March).

Morck, Randall et al. (2000) "The information content of stock markets: why do emerging markets have synchronous stock price movement?" Journal of Financial Economics 58: 215- 260.

OECD [Organization for Economic Cooperation and Development] (2002) China in The World Economy: The Domestic Policy Challenges, OECD: Paris.

Oppenhoff, Walter and Thomas O. Verhoeven (2003) "Stock corporations," in Bernd Rüster (ed.), Business Transactions in Germany, Matthew Bender.

Peerenboom, Randall (2002) China's Long March Toward Rule of Law, Cambridge: Cambridge University Press.

[PBOC] People's Bank of China (2006) "Zhongguo huobi zhengce zhixing baogao er ling ling liu nian diyi jidu 2006 [Report on the implementation of China's monetary policy, first quarter 2006]" (31 May).

Ping, Hu and Jing Li (2000) "Jijin heimu [The inside story on investment funds]," Caijing [Finance and Economics], 31 (5 October). Available at http://www.caijing. com.cn/ele/31.shtml.

Pistor, Katharina and Chenggang Xu (2004) "Governing stock markets in transition economies: lessons from China," Columbia Law and Economics Working Paper No. 262 (November 2004). Online at http://ssrn.com/abstract $=628065$.

Qi, Daqing et al. (2000) "Shareholding structure and corporate performance of partially privatized firms: evidence from listed Chinese companies," Pacific-Basin Financial Journal 8: 587-610.

Roe, Mark J. (1994) Strong Managers, Weak Owners: The Political Roots of American Corporate Finance, Princeton, NJ: Princeton University Press.

(2004) "The institutions of corporate governance," Harvard University, John M. Olin Center for Law, Economics, and Business Discussion Paper No. 488 (August 2004). Online at http://ssrn.com/abstract $=612362$.

Securities Industry Association (2003) "Written statement of the securities industry association," in United States-China Economic Relations and China's Role in the 


\section{Donald C. Clarke}

Global Economy: Hearings Before the House Commission on Ways and Means, 108th Congress. Available at http://www.sia.com/testimony/2003/siatestimony1003.html.

Securities Law (2005) "Zhonghua renmin gongheguo zhengquan fa [Securities law of the People's Republic of China]" (as amended 27 October 2005, effective 1 January 2006).

Shleifer, Andrei and Robert Vishny (1997) "A survey of corporate governance," Journal of Finance 52: 737-783.

Tenev, Stoyan and Chunlin Zhang (2002) Corporate Governance and Enterprise Reform in China: Building the Institutions of Modern Markets, Washington, DC: World Bank and International Finance Corporation.

Studwell, Joe (2002) The China Dream: The Quest for the Last Untapped Market on Earth, London: Profile Books.

$\mathrm{Su}$, Dongwei (2000) "Corporate finance and state enterprise reform in China" (18 November). Online at http://ssrn. com/abstract $=250802$.

Tian, Jenny J. and Chung-Ming Lau (2001) "Board composition, leadership structure and performance in Chinese shareholding companies," Asia Pacific Journal of Management 18: 245-263.

Tianjin Daily (2001) "Woguo zhen gumin buguo yiqian wan [True shareholders in China not more than ten million]," Tianjin Ribao [Tianjin Daily], 3 (13 December).

U.S. Commercial Service [Department of Commerce] (2007) "Banking--U.S. Commercial Service China." Available at http://www.buyusa.gov/china/en/bank.html (accessed 1 September 2007)

Walter, Carl E. and Fraser J.T. Howie (2003) Privatizing China: The Stock Markets and Their Role in Corporate Reform, Indianapolis: John Wiley \& Sons.

Wang, Changbo and Hualan Feng (2002) "Lun duli dongshi zhidu yu jianshihui zhidu xiang jiehe de jian guan moshi [On the monitoring model combining the independent director system and the system of the board of supervisors]," Shengchanli Yanjiu [Research in Productive Forces] 1: 119-121.

$\mathrm{Xu}$, Xiaonian and Yan Wang (1999) "Ownership structure and corporate governance in Chinese stock companies," China Economic Review 10: 75-98.

$\mathrm{Xu}$, Yongqian and Yulong Li (2001) "Gongsi zhili yu gudong baohu [Corporate governance and the protection of shareholders]," paper for 21st Century Commercial Law Forum, Qinghua University (18 November 2001)

Yang, Shuming and Zhang, Ping (2000) "Chongsu gongsi faren zhili jichu xin linian: suoyou yu jingying fenli de tongyi [A new concept for recreating the basis of corporate governance: the unity of the separation of ownership and management]," Xiandai Faxue [Modern Legal Studies] 5: 18-21.

Young, Michael N. and Pamela Mar (2001) "Corporate governance in transition economies: a case study of two Chinese airlines," Journal of World Business 36: 280-302.

Zhang, Yelin (2004) "The roles of corporatization and stock market listing in reforming China's state industry," World Development 32: 2031-2047. 